\title{
Teachers' Digital Skills Readiness During COVID-19 Pandemic
}

\author{
https://doi.org/10.3991/ijet.v16i08.21011
}

\author{
Maria Perifanou ${ }^{(凶)}$, Anastasios A. Economides, Katerina Tzafilkou \\ University of Macedonia, Thessaloniki, Greece \\ mariaperifegmail.com
}

\begin{abstract}
The COVID-19 crisis revealed the necessity for teachers to have digital skills in order to effectively teach online. Teachers should be able to exploit, use, and apply digital technologies in all educational activities. This paper investigates teachers' perceptions regarding their digital skills for performing their teaching and professional responsibilities during the pandemic. More than eight hundred teachers participated in a survey regarding the use of digital technologies in their teaching and their professional responsibilities. Indicative digital tools that can be used by digital competent teachers are also presented to cover all areas of the teachers' professional activities. Their answers revealed that they mostly used digital tools for finding, evaluating, and developing educational resources as well for teaching. They also used digital tools for self-study, students' assessment, as well as interacting and communicating with students. However, they hardly used digital tools for other teaching activities such as feedback and final evaluation of the students, or revising the educational resources. Finally, they could not deal with long-term planning, management, and development of either their school or education in general. Although it is important for teachers to effectively respond to their daily emergent teaching responsibilities, consideration should also be given to the long-term planning and development of the digital school and digital education in general.
\end{abstract}

Keywords - Continuing Education; Digital Skills; Digital Readiness; Digital Teaching; Teacher Digital Skills; Teacher Professional Development

\section{Introduction}

The emergent situation due to the COVID-19 pandemic exhibited the necessity for all teachers and students to have digital skills. In order to slow down the pandemic outbreak, governments all over the world enforced lockdown measures which also affected schools. Educational activities were heavily disrupted in most countries. In more than one hundred sixty countries the schools closed preventing $87 \%$ of students from attending face-to-face classes [1]. More than sixty million teachers had to deliver their teaching thought digital means and more than one and half billion students had to participate in online classes from their home [1]. 
However, not all education systems and teachers were ready for this shift to online teaching and learning [2]. In most countries, teachers had limited digital skills and experience of online teaching and learning [3 - 5]. The pandemic lockdown exposed the urgent need for all teachers to be able to use digital technologies effectively for online teaching and learning [2]. However, just before the pandemic outburst, more than $60 \%$ of teachers in the EU did not feel well or very well prepared to use digital technologies for teaching [6]. Although teachers felt confident using digital technologies for simple tasks, they felt less confident in more complex digital tasks such as coding, programming, or robotics. In OECD countries, about only $65 \%$ of teachers had the necessary technical and pedagogical skills to use digital devices in teaching [7, 8]. Also, only 53\% of teachers permitted their students to frequently or always use digital technologies for projects or assignments [7 - 9].

Currently, it became obvious the importance of all teachers having digital skills [2]. Among the top priorities of EU [10], it is to support the teachers' initial education and continuing professional development on digital skills and innovative pedagogies. The "Education and Training Monitor" report [11] emphasized that teachers' qualifications, professional development, as well as teaching experience and practices are necessary for quality education. Equipping teachers with quality initial education, as well as supporting their continuous professional development and collaboration can increase their teaching effectiveness.

According to the Department of Education [12], many pre-service teacher education graduates do not feel qualified to use technology for teaching. In an OECD [7, 8, 9] survey, only $60 \%$ of teachers received training in digital technologies during the previous year, while $18 \%$ of teachers urgently need digital technologies training. Similarly, EU teachers ask for training on digital skills for teaching. In several EU countries (Austria, Croatia, Czechia, Denmark, Lithuania, Netherlands, Portugal, Spain, Sweden), less than half of the teachers had used digital technologies for teaching in their initial teacher education [6]. Furthermore, more than $60 \%$ of EU students are taught by teachers who had been trained on digital technologies in their spare time [6]. So, most EU teachers spend their free time to develop digital skills [13].

There are many different definitions regarding what constitutes teachers' digital skills [13]. Although there is much research regarding digital skills in education, there is a confusion between the basic digital skills of average citizens and the digital skills of teachers $[14,15]$. This may happen because teachers' digital skills include a large variety of knowledge and skills regarding digital technologies and their application into the teaching practice [16]. In addition to the disagreement on the definition of teachers' digital skills [15, 17], various related concepts (e.g., teachers' ICT competence, ICT skills, digital competence, digital literacy, digital pedagogy, pedagogical digital skills, professional digital skills) are often used as synonyms. However, all definitions emphasize that teachers should be able to effectively use the digital technologies and integrate them into their teaching and learning practices.

Ref. [18] suggested six domains for teachers' skills: technological, pedagogical, didactic, evaluative, communicational and attitudinal [18]. Another study [19] proposed two sub-domains for teachers' digital skills: Technological and pedagogical skills. In addition, the technological skills influence the pedagogical skills [19]. As stated in [20] 
teachers' digital skills include the teachers' skills to use digital technologies for searching, evaluating, and using educational material on the Internet.

The "European framework for the digital competence of educators" "DigCompEdu" [21] is one of the most well-known frameworks to describe teachers' digital skills. It aims to describe teachers' digital skills by proposing twenty-two fundamental skills organized in six domains and six different proficiency levels. Fifteen European countries (Austria, Bulgaria, Cyprus, Czechia, Estonia, Finland, France, Portugal, Serbia, Slovenia, Switzerland Spain, United Kingdom -ENG, WLS, and NI) adopted the use of self-assessment tools to enable teachers to self-evaluate their proficiency level of digital skills, identify their needs and plan their professional development. Six countries (Cyprus, Czechia, Estonia, Portugal, Slovenia, and Spain) adopted the European self-assessment tool and the rest countries developed their own self-assessment tools [13]. Ref. [22] explored the "DigCompEdu" Check-In questionnaire composed of twenty-two items. Each item corresponds to a statement "I use digital technologies to ..." with five answers: "Not at all", "Not really", "Sometimes", "Yes, I use different digital tools", "Yes, I follow a structured approach integrating different digital tools". Among one hundred sixty Moroccan English teachers who answered it, teachers with more years of teaching experience and those with a higher level of digital teaching confidence achieved higher digital skills scores. Furthermore, teachers were less competent with regards to students' digital assessment, self-regulated learning, accessibility, and personalization. Similarly, Ref. [23] used the "DigCompEdu" CheckIn questionnaire and found that moderately higher digital skills scores were achieved by more experienced teachers in using digital technologies in teaching. Moreover, significantly higher scores were achieved by teachers who exploit a larger variety of digital teaching strategies. There was also a small difference in digital skills between STEM and non-STEM teachers as well as computer science and non-computer science teachers. Inspired by "DigCompEdu", Ref. [24] developed a questionnaire of thirty-five questions to investigate teachers' confidence in using both digital resources and online methods in teaching. Three hundred primary and secondary education teachers from four European countries (Cyprus, Greece, Slovakia, and Spain) answered the questionnaire. There were found significant differences between countries, regarding teachers' confidence. Furthermore, it was found that both the teachers' educational qualification and their level of continuous professional development significantly predict the teachers' confidence.

Similarly, UNESCO [25] developed the "ICT Competency Framework for Teachers" (ICT CFT) to inform pre- and in-service teachers training on the use of digital technologies in education. The "ICT CFT" includes 18 competencies organized in six domains of teachers' professional practice, and three proficiency levels. Many educational systems (e.g., Egypt, Kenya, Tunisia, Rwanda, South Africa, Togo, Zimbabwe) have adopted UNESCO's "ICT CFT" localized it for the specific context [13], [25]. Ref. [26] investigated the teacher's ability to use ICT for teaching as well as provide to his/her students opportunities of using ICT. Furthermore, Ref. [27] found that the more pre-service teachers experience multiple strategies during their teacher education, the higher their perceived competence to use digital technologies for teaching and learning. 
The "International Computer and Information Literacy", ICILS 2018, teachers' survey [28] found that most teachers had high confidence on their ability to find useful educational resources on the Internet $\rightarrow(95 \%)$ create presentations with simple animations (84\%), organize educational activities with students using digital tools (84\%), and assess students (78\%) [28]. However, they had low confidence for using a learning management system (59\%), contributing to an online discussion (58\%), and collaborating with others over shared platforms $(57 \%)$ [28].

In the face of COVID-19, teachers must be able to effectively use digital technologies for teaching and supporting their students [29]. The studies above investigated the teachers' abilities to use digital technologies in the teaching practice before the COVID19 times. In this paper, we investigate Greek teachers' digital readiness to effectively perform not only teaching but all of their professional activities during the pandemic times. A questionnaire was answered by 806 Greek teachers in primary and secondary education. Their answers revealed in which areas their digital skills were either strong or weak. A set of indicative digital tools for each specific area is presented in the Appendix (Table 2). Conclusions and suggestions for future research are also given.

\section{$2 \quad$ A Survey on Greek Teachers' Digital Skills During Pandemic}

Before the COVID-10 pandemic, only one-third of Greek students attended classes in Greek schools with an effective online learning platform [9]. Also, less than twothird of Greek students were taught by digital competent teachers. During the schools' closure due to the pandemic (March to May 2020), the Panhellenic School Network (https://www.sch.gr/) provided networking and educational services as well as access to educational resources to over one-hundred fifty thousand teachers and over 1 million students of primary \& secondary education. More than one hundred thousand teachers created at least one personal digital class and three-quarter million students participated in these digital classes daily [30].

In order to record the teachers' digital skills readiness to cope with the new educational conditions during the pandemic, a survey was organized targeting primary and secondary education in-service teachers. During the last years, Greek governments organized a series of teachers' training programs on how to exploit digital technologies in the teaching practice. The survey was organized during such a training program during the pandemic. More than 5800 primary and secondary education in-service teachers participated in a 60-hours blended training that included 42-hours online synchronous and asynchronous teaching and learning as well as 18-hours on-site practicing from March to June 2020. They were supported by an asynchronous distance education, elearning management, and training material distribution system. However, most of the on-site practicing was shifted to distance education due to the pandemic lockdown. Furthermore, Greek government started another large-scale teachers' training program during winter 2020 in order to fast train all Greek teachers in the implementation of distance education. So, it is expected that all 163,104 Greek teachers in primary and secondary education will have at least basic digital skills for the digital school. 
An online questionnaire was administered to these 5800 teachers in June. 806 teachers anonymously and voluntarily filled out the questionnaire. The questionnaire was based on the "Teachers' Digital Competence" (TeDiCo) Framework [31].

Most of these teachers were women $(75 \%)$ and their age was between 30 and 60 years old (22\% 30-40 years old; 42\% 41-50 years old; 34\% 51-60 years old). Most of them hold a M.Sc. degree (50\%) as the highest degree, and few hold a Ph.D. degree $(6.5 \%)$. Most of them had 10-20 years of teaching experience $(56 \%)$, while the rest had $21-30$ years $(30 \%)$, less than 10 years $(8 \%)$, and more than 31 years $(6 \%)$ of teaching experience. They had teaching experience using digital technologies as follows: less than 5 years $(25 \%), 5-10$ years $(36 \%), 11-15$ years $(21 \%), 16-20$ years $(12 \%)$, and more than 20 years $(6 \%)$. Table 1 shows the average scores of their answers to the questions.

Table 1. The average scores of teachers' digital skills

\begin{tabular}{|c|c|c|c|c|c|c|}
\hline $\begin{array}{l}\text { To what extent (intensity, quantity, and frequency) do you use digital } \\
\text { tools for the following? } \\
1 \text { = "not at all", } 2 \text { = "little /low", } 3=\text { "average", } 4=\text { "very } / \text { high", } 5= \\
\text { "excellent" }\end{array}$ & $\begin{array}{l}\text { Average } \\
\text { Score }\end{array}$ & $\begin{array}{l}1 \\
\%\end{array}$ & \begin{tabular}{l|l}
2 \\
$\%$
\end{tabular} & \begin{tabular}{l|l}
3 \\
$\%$
\end{tabular} & $\begin{array}{l}4 \\
\%\end{array}$ & $\begin{array}{l}5 \\
\%\end{array}$ \\
\hline $\begin{array}{l}\text { I use, attend, and study online courses (e.g., MOOCs), OERs, e-books, e- } \\
\text { journals, and other digital educational materials for professional self-devel- } \\
\text { opment. }\end{array}$ & 3.38 & 8 & 17 & 26 & 27 & 22 \\
\hline $\begin{array}{l}\text { I collaborate and participate in online teacher communities, online confer- } \\
\text { ences \& seminars, and other social media for professional self-development. }\end{array}$ & 2.23 & 12 & 19 & 22 & 28 & 19 \\
\hline $\begin{array}{l}\text { I use and manage digital tools for the management \& administration of the } \\
\text { school (e.g., digital recording attendance and grades, time-planning of clas- } \\
\text { ses and events, online collaboration with parents, teachers, other schools, } \\
\text { and ministry). }\end{array}$ & 2.98 & 16 & 22 & 24 & 24 & 14 \\
\hline $\begin{array}{l}\text { I use and manage digital tools for curriculum development \& management } \\
\text { (e.g., software for recording the coverage of educational material from dif- } \\
\text { ferent classes, departments, and teachers, as well as comparing the progress } \\
\text { of students from different classes and departments). }\end{array}$ & 2.17 & 39 & 26 & 19 & 11 & 5 \\
\hline $\begin{array}{l}\text { I use and manage digital tools for the development \& management of the } \\
\text { school's infrastructure and resources (e.g., scheduling software for the use } \\
\text { of laboratories and equipment by different departments and teachers; up- } \\
\text { grading and maintenance of technological equipment). }\end{array}$ & 1.94 & 50 & 21 & 17 & 9 & 3 \\
\hline $\begin{array}{l}\text { I use and manage digital tools for the development \& management of the } \\
\text { school's quality assurance (e.g., digital tools for recording problems, com- } \\
\text { plaints, recommendations, etc. and monitoring their resolution; comparative } \\
\text { analysis of student performance in national exams between different clas- } \\
\text { ses). }\end{array}$ & 1.71 & \begin{tabular}{|l|}
59 \\
\end{tabular} & 21 & 13 & 5 & 2 \\
\hline $\begin{array}{l}\text { I use digital technologies to generate research and innovation in education } \\
\text { (e.g., statistical analysis of questionnaires to identify important parameters } \\
\text { that affect learning; creation of educational software for the development of } \\
\text { simulations). }\end{array}$ & 2.21 & 40 & 24 & 18 & 11 & 7 \\
\hline $\begin{array}{l}\text { I use digital technologies to support quality assurance in education (e.g., sta- } \\
\text { tistical analysis of student performance \& career; statistical analysis of } \\
\text { teacher training programs from different schools, regions, and states). }\end{array}$ & 1.65 & 64 & \begin{tabular}{l|l}
18 \\
\end{tabular} & 11 & 5 & 2 \\
\hline $\begin{array}{l}\text { I use digital tools to identify and analyze the needs and characteristics of } \\
\text { students, as well as the available resources, devices, and infrastructure for } \\
\text { my lessons. }\end{array}$ & 2.64 & 21 & 26 & 27 & 19 & 7 \\
\hline $\begin{array}{l}\text { I use search engines, digital repositories, databases, and test banks to ex- } \\
\text { plore, find, and evaluate existing educational resources (e.g., OERs) using } \\
\text { various criteria, metadata filters, and recommender systems. }\end{array}$ & 3.67 & 4 & 10 & 24 & 39 & 23 \\
\hline
\end{tabular}


I use digital tools for editing, authoring, and managing text, presentations, audio, picture, video, games, blogs, wiki, quizzes, tests, etc. to develop new (or modify and combine existing) educational resources.

I use a digital calendar, time-planning, and project management software to plan, organize, and schedule the most appropriate educational resources for teaching.

I use software for project, school and classroom management, learning management systems, plagiarism, and security software to manage the lesson, classroom, activities, students, educational resources, devices, and infrastructure, etc.

I use digital presentations, video conferencing, webinars, video platforms, digital distribution \& sharing tools, simulations \& serious games, online lab \& virtual experiments to teach (e.g., present, demonstrate, explain) the students.

I use digital communication and collaboration technologies (e.g., web conferencing, digital sharing and group collaboration tools, interactive whiteboards, project management software, wiki tools, social media, and collaboration games) to interact, communicate and collaborate with students.

I use digital assessment technologies (e.g., digital quizzes, tests, questions, exercises, assignments, inquiries, web quests) to periodically assess the students' progress.

I use digital monitoring tools (e.g., remote desktop control \& screen sharing), dashboards, and learning analytics to monitor students' activities, interactions, relationships, mood, and performance, as well as the teaching process, educational resources, equipment, and infrastructure.

I use learning management systems, software for reminding, annotations, auto-correction, chatbots, avatars, recommendation systems to guide, feedback, advise, support, and inspire students.

I use digital diaries, blogs, concept mapping, mind mapping, digital tools for recording thoughts, voice, photos, videos, self-assessment, etc. to record my thoughts, feelings, behavior, and performance as well as those of my students, as well as the use and quality of educational resources, equipment, and infrastructure, and then to reflect on (and review) them.

I use information from digital monitoring, evaluation, and reflection tools to continuously adapt my teaching using digital technologies.

I use digital evaluation tools (e.g., student examination, school management tools, safety, and technology performance evaluation software) to evaluate students, my teaching, educational resources, devices, and infrastructure. I use information from monitoring, testing, and evaluation tools to revise the preparation, delivery, and evaluation of my teaching using digital technologies.

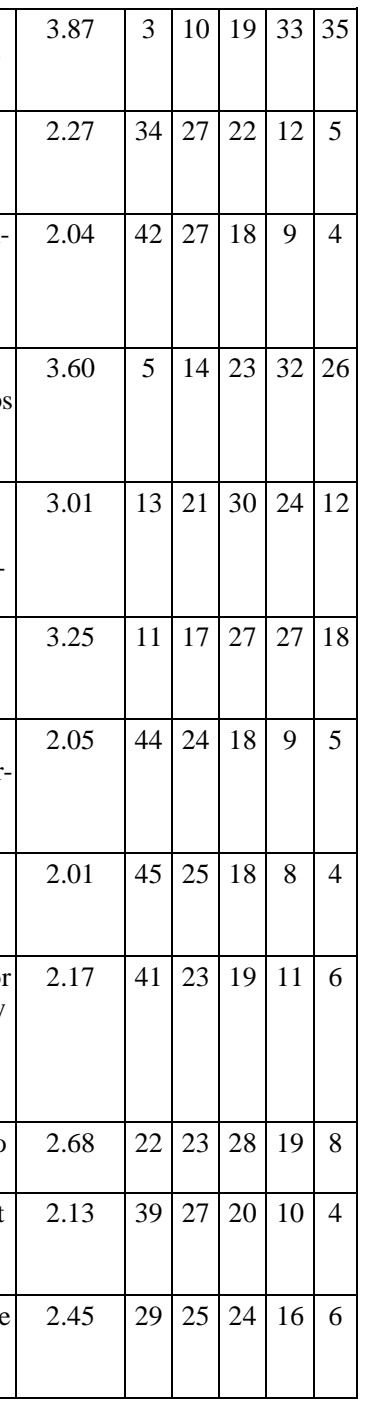

It is interesting that teachers did not scored very high (average score above 4) to none digital skill. On average, they definitely did not consider themselves as experts in any digital skill.

About two-third of Greek teachers used digital tools extensively for: 1) developing educational resources; 2) searching and finding educational resources; and 3) teaching the students. More specifically, the following answers to the question "To what extent (intensity, quantity, and frequency) do you use digital tools" achieved the highest average scores: 
- "I use digital tools for editing, authoring, and managing text, presentations, audio, picture, video, games, blogs, wiki, quizzes, tests, etc. to develop new (or modify and combine existing) educational resources" (av. score=3.87)

- "I use search engines, digital repositories, databases, and test banks to explore, find, and evaluate existing educational resources (e.g., OERs) using various criteria, metadata filters, and recommender systems" (av. score $=3.67$ )

- "I use digital presentations, video conferencing, webinars, video platforms, digital distribution \& sharing tools, simulations \& serious games, online labs \& virtual experiments to teach (e.g., present, demonstrate, explain) the students" (av. score= $3.60)$.

It is worth noting that they also used digital technologies above average for selfstudy, students' formative assessment, as well as interacting and communicating with students. Almost half of them used digital tools extensively for self-study and students' formative assessment. More specifically, the following answers to the question "To what extent (intensity, quantity, and frequency) do you use digital tools" achieved high average scores:

- "I use, attend, and study online courses (e.g., MOOCs), OERs, e-books, e-journals, and other digital educational materials for professional self-development" (av. score $=3.38$ )

- "I use digital assessment technologies (e.g., digital quizzes, tests, questions, exercises, assignments, inquiries, web quests) to periodically assess the students' progress" (av. score $=3.25)$

- "I use digital communication and collaboration technologies (e.g., web conferencing, digital sharing and group collaboration tools, interactive whiteboards, project management software, wiki tools, social media, and collaboration games) to interact, communicate and collaborate with students" (av. score $=3.01$ ).

However, more than half of the teachers did not use at all or they used a little digital tools for the following activities: i) curriculum development \& management, ii) generating research and innovation in education, iii) planning and scheduling the teaching and educational resources, iv) managing the course, the students, the educational resources and activities, v) monitoring the students and the educational resources, vi) guidance and feedback to the students, vii) self-reflection viii), ix) adapting the instruction, $\mathrm{x}$ ) evaluating the students (summative assessment) and the educational resources, and xi) revising the educational resources, teaching, and assessment.

Finally, almost three quarters of the teachers did not use at all or they used little digital tools for: 1) supporting the quality assurance in education; 2) the development $\&$ management of the school's quality assurance; and 3) the development \& management of the school's infrastructure and resources. More specifically, the following answers to the question "To what extent (intensity, quantity, and frequency) do you use digital tools" achieved the lowest average scores: 
- "I use digital technologies to support quality assurance in education (e.g., statistical analysis of student performance \& career; statistical analysis of teacher training programs from different schools, regions, and states)" (av. score= 1.65)

- "I use and manage digital tools for the development \& management of the school's quality assurance (e.g., digital tools for recording problems, complaints, recommendations, etc. and monitoring their resolution; comparative analysis of student performance in national exams between different classes)" (av. score=1.71)

- "I use and manage digital tools for the development \& management of the school's infrastructure and resources (e.g., scheduling software for the use of laboratories and equipment by different departments and teachers; upgrading and maintenance of technological equipment" (av. score= 1.94).

It seems that teachers mainly used digital tool for their daily teaching delivery. They also used digital tools for self-study as well as continuously assessing and interacting with students. They hardly used digital tools for other teaching activities such as feedback and final evaluation of the students, or revising the educational resources. Finally, they could not deal with long-term planning, management, and development of either their school or education in general.

\section{Conclusions and Future Research}

This paper provides insights on the teachers' digital skills and use of digital technologies during the COVID-19 pandemic. The answers of 806 teachers in primary and secondary education in Greece revealed that about two-third of them used digital tools extensively for finding, evaluating, and developing educational resources as well for teaching. Almost half of them used digital tools extensively for self-study and students' formative assessment. They also used digital tools for interacting and communicating with students. However, they hardly used digital tools for other teaching activities such as feedback and final evaluation of the students, or revising the educational resources. Finally, almost three quarters of them did not use at all or they used a little digital tool for supporting and advancing their school and education in general. Since, education is fast moving to a digital education mode, teachers and educational authorities should carefully plan for the future. Although their daily teaching responsibilities are urgent, teachers should also give serious considerations to their other instructional activities as well as the planning and future development of the digital school and the digital education. Furthermore, all teachers should receive advance training on utilizing and exploiting the digital technologies in all of their professional activities. Finally, the paper provides a list of digital tools that can be used by teachers to accomplish their obligations in various educational areas (Appendix).

The survey participants were Greek teachers who have just completed a short training on using and applying digital technologies in their teaching practice. At that time not all Greek teachers had attended such training. Currently, almost all Greek teachers have or are attending such training. So, we expect that the survey outcomes are representative of all Greek teachers' digital skills levels. In the future, we plan to investigate 
the teachers' digital skills and the use of digital technologies in their profession from an international body of teachers.

Of course, this survey has some limitations. Like all similar questionnaires, it records the opinions of the teachers about their personal digital skills. So, it does not objectively evaluate their real digital skills and the real usage of digital tools. However, to objectively test a teacher's digital skills, a teacher needs to spend many hours to complete laborious tests using specialized software and equipment. Future research could try to develop such practical tests to assess specific digital skills of teachers (e.g. editing, authoring, and managing video for educational purposes; security monitoring and management of the school's resources and devices). Furthermore, real-time monitoring and measuring teachers' activities in using digital tools may conflict with privacy and confidentiality issues.

\section{Acknowledgement}

The authors would like to thank the following colleagues for their valuable help: Chatziplis P., Dagdilelis B., Egarchou D., Georgiadou E., Lambrinos Y., Leventis A., Triantafyllou V., Vouzaxakis G. and Zagouras C.

\section{$5 \quad$ References}

[1] UN, "Shared responsibility, global solidarity: Responding to the socio-economic impacts of COVID-19”. United Nations 2020. https://www.un.org/sites/un2.un.org/files/sg_report_socio-economic impact of covid19.pd. https://doi.org/10.18356/5c353f7e-en

[2] European Commission, "Digital education action plan 2021-2027. Resetting education and training for the digital age". COM (2020) 624.

[3] C. Bossu, R. Smyth and S. Stein, "Academic professional development for effective e-learning: A possible framework for Brazil," International Journal of Emerging Technologies in Learning, vol. 2, no. 4, pp. 48-53, 2007.

[4] N.T. Nguyen, T.V. Thai, H.T. Pham and G.C.T. Nguyen, "CDIO approach in developing teacher training program to meet requirement of the industrial revolution 4.0 in Vietnam," International Journal of Emerging Technologies in Learning, vol. 15, no. 18, pp. 108-123. 2020. https://doi.org/10.3991/ijet.v15i18.15517

[5] P. Phuapan, C. Viriyavejakul and P. Pimdee, "An analysis of digital literacy skills among Thai university seniors". International Journal of Emerging Technologies in Learning, vol. 11, no. 3, pp. 24-31. 2016. https://doi.org/10.3991/ijet.v11i03.5301

[6] European Commission, "2nd Survey of Schools: ICT in Education," 2019. Retrieved on 1112-2019 from: https://ec.europa.eu/digital-single-market/en/news/2nd-survey-schools-icteducation

[7] OECD [Organisation for Economic Co-operation and Development], "PISA 2018 Results (Volume I): Where all students can succeed," Annex B21PISA, OECD Publishing, Paris, 2020. https://www.oecd-ilibrary.org/education/pisa-2018-results-volume-i_5f07c754-en. https://doi.org/10.1787/f7986824-en

[8] OECD [Organisation for Economic Co-operation and Development], "PISA 2018 Results (Volume V): Effective policies, successful schools, ” PISA, OECD Publishing, Paris, 2020, https://doi.org/10.1787/ca768d40-en. https://doi.org/10.1787/56520d67-en 
[9] OECD [Organisation for Economic Co-operation and Development], "TALIS - The OECD teaching and learning international survey". OECD, 2020. Retrieved on 11-12-2019 from: http://www.oecd.org/education/talis/. https://doi.org/10.1787/271fd86a-en

[10] Education and Training 2020, “Working group mandates 2018-2020”. 2019. Retrieved on 11-12-2019 from: https://ec.europa.eu/education/sites/education/files/document-librarydocs/et2020_mandates_2018-2020_final.pdf

[11] European Commission, "Education and training monitor report". 2019. DOI: 10.2766/28521 NC-AJ-18-001-EN-N, Retrieved on 11-12-2019 from: https://ec.europa.eu/education/sites/education/files/document-library-docs/volume-1-2019-educationand-training-monitor.pdf

[12] OET, "Reimagining the role of technology in Education: 2017 National Education Technology Plan Update". Office of Educational Technology. U.S. Department of Education, 2017. Retrieved on 4-5-2018 from: https://tech.ed.gov/files/2017/01/NETP17.pdf

[13] Eurydice Report, "Digital education at school in Europe". Education, Audiovisual and Culture Executive Agency, 2019. DOI:10.2797/763, Retrieved on 11-12-2019 from: https://eacea.ec.europa.eu/national-policies/eurydice/sites/eurydice/files/en digital education_n.pdf. https://doi.org/10.5944/reec.19.2012.7587

[14] S. Virkus, "Information literacy in Europe: Ten years later". In S. Kurbanoğlu et al. (Eds.): ECIL 2013, CCIS 397, 2013. pp. 250-257.

[15] F. Pettersson, "On the issues of digital skills in educational contexts - A review of literature," Education and Information Technologies, 23(3), 1005-1021, 2018. DOI: 10.1007/s10639017-9649-3

[16] J. From, "Pedagogical digital competence-Between values, knowledge and skills," Higher Education Studies, vol. 7, no. 2, pp. 43-50, 2017. https://doi.org/10.5539/hes.v7n2p43

[17] M. Spante, S.S. Hashemi, M. Lundin, M. and A. Algers, "Digital skills and digital literacy in higher education research: Systematic review of concept use," Cogent Education, vol. 5, no. 1, 2018. https://doi.org/10.1080/2331186x.2018.1519143

[18] A. Guzman and M. Nussbaum, "Teaching competencies for technology integration in the classroom," Journal of Computer Assisted Learning, vol. 20, no. 5, pp. 453-469, 2009. https://doi.org/10.1111/j.1365-2729.2009.00322.x

[19] G. Almerich, N. Orellana, J. Suarez-Rodríguez and I. Díaz- García, "Teachers' information and communication technology competences: A structural approach," Computers \& Education, vol. 100, pp. 110-125, 2016. https://doi.org/10.1016/j.compedu.2016.05.002

[20] N. Tsankov and I. \& Damyanov, "Education majors' preferences on the functionalities of elearning platforms in the context of blended learning," International Journal of Emerging Technologies in Learning, vol. 12, no. 5, pp. 202-209, 2017. https://doi.org/10.3991/ ijet.v12i05.6971

[21] C. Redecker, "European framework for the digital skills of educators: DigCompEdu". Punie, Y. (ed). EUR 28775 EN. Publications Office of the European Union, Luxembourg, 2017. JRC107466. DOI:10.2760/159770

[22] M. Benali, M. Kaddouri and T. Azzimani, "Digital skills of Moroccan teachers of English," International Journal of Education and Development using Information and Communication Technology (IJEDICT), vol. 14, no. 2, pp. 99-120, 2018.

[23] M. Ghomi and C. Redecker, "Digital skills of educators (DigCompEdu): Development and evaluation of a self-assessment questionnaire for teachers' digital skills." In CSEDU (1), pp. 541-548, 2019. https://doi.org/10.5220/0007679005410548

[24] M. Perifanou, L. Neophytou, Z. Petrova, N. Castells Gomez and F. Antoniou, "Investigating teachers' confidence and training needs on digital literacy across four European countries," INTED2019 Proceedings, pp. 6808-6817, 2019. https://doi.org/10.21125/inted.2019.1655

[25] UNESCO, "ICT competence framework for teachers (ICT-CFT)," 2018. ISBN 978-92-3100285-4. 
[26] J. Tondeur, K. Aesaert, B. Pynoo, J. van Braak, N. Fraeyman and O. Erstad, "Developing a validated questionnaire to measure preservice teachers' ICT competencies: Meeting the demands of the 21st century," British Journal of Educational Technology, vol. 48, no. 2, pp. 462-472, 2017. https://doi.org/10.1111/bjet.12380

[27] J. Tondeur, R. Scherer, E. Baran, F. Siddiq, T. Valtonen and E. Sointu, "Teacher educators as gatekeepers: Preparing the next generation of teachers for technology integration in education," British Journal of Educational Technology, vol. 50, pp. 1189-1209, 2019. https://doi.org/10.1111/bjet.12748

[28] J. Fraillon, J. Ainley, W. Schulz, T. Friedman and D. Duckworth, "Preparing for Life in a Digital World: IEA International Computer and Information Literacy Study 2018 International Report". Amsterdam: International Association for the Evaluation of Educational Achievement (IEA), 2019. https://doi.org/10.1007/978-3-030-38781-5_3

[29] R. Winthrop, "Top 10 risks and opportunities for education in the face of COVID-19". The Brookings Institution, 2020, Retrieved on 11-11-2020 from: https://www.brookings.edu/blog/education-plusdevelopment/2020/04/10/top-10-risks-and-opportunities-foreducation-in-the-face-of-covid-19/

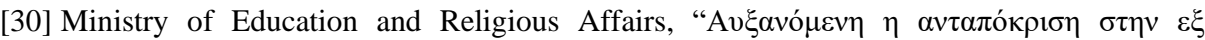
$\alpha \pi \circ \sigma \tau \alpha \dot{\sigma} \sigma \varepsilon \omega \varsigma \varepsilon \kappa \pi \alpha i ́ \delta \varepsilon v \sigma \eta, ” 2020$. Retrieved on 5-5-2020 from: https://www.minedu.gov.gr/ news/44813-05-05-20-afksanomeni-iantapokrisi-stin-eks-apostaseos-ekpaidefsi-2

[31] M. Perifanou and A. A. Economides. Teachers' digital competence (TeDiCo) framework [under peer review].

\section{Authors}

Maria Perifanou is a Lecturer at the Aristotle University of Thessaloniki, an adjunct faculty member at the Hellenic Open University, and a Senior Researcher at the Smart and Mobile Learning Environments (SMILE) Lab of the University of Macedonia (GR) in the field of CALL and TEL. She has coordinated and collaborated with many European research institutions on more than 35 EU projects. She holds a Master degree in ICT and Foreign Language education from Ca' Foscari, University of Venice, (IT) and a Ph.D. from the University of Athens, (GR), in the field of Applied Linguistics. She has coordinated and collaborated with many European research institutions on more than 35 EU projects. Her research interests include CALL, TEL, MOOCs, OERs, Teachers Training.

Anastasios A. Economides is a Professor at the University of Macedonia (UoM), Thessaloniki, Greece. He is the Director of SMILE (Smart \& Mobile Interactive Learning Environments) lab at UoM. He holds a M.Sc. (1987) and a Ph.D. (1990) degree in Computer Engineering, University of Southern California, Los Angeles. His research interests include personalised \& collaborative learning \& assessment; digital skills; online teaching and learning; user experience \& acceptance of smart systems \& service. He has received over 6000 citations, h-index $=41$, i10index $=115$, (2020).

Katerina Tzafilkou is a postdoctoral researcher in the field of Technology Enhanced Learning (TEL) and Emotion Recognition in University of Macedonia (GR). She holds a Ph.D. and a M.Sc. degree in Information Systems, and a B.Sc. in International and European Studies. She is also a lecturer in the International Hellenic University (GR).

Article submitted 2021-01-10. Resubmitted 2021-02-07. Final acceptance 2021-02-09. Final version published as submitted by the authors. 


\section{$7 \quad$ Appendix}

Table 2. Digital tools used by teachers in various professional activities

\begin{tabular}{|c|c|}
\hline Teacher's activities & Digital tools \\
\hline $\begin{array}{l}\text { School's Management \& } \\
\text { Administration }\end{array}$ & $\begin{array}{l}\text { Alma, Open-School Community, EduSec College Management System, Sky- } \\
\text { ward School Management, Snapii, SAF School Management Software, Mon- } \\
\text { day.com. }\end{array}$ \\
\hline $\begin{array}{l}\text { Curriculum development \& } \\
\text { management }\end{array}$ & $\begin{array}{l}\text { Atlas, Coursetune, Eduplanet21, BuildYourOwnCurriculum, CourseLeaf \& } \\
\text { Curriculum. }\end{array}$ \\
\hline $\begin{array}{l}\text { School's Infrastructure \& } \\
\text { Resources }\end{array}$ & $\begin{array}{l}\text { Auvik, EZOfficeInventory, Jira Service Desk, Spiceworks, Freshservice, } \\
\text { SysAid. }\end{array}$ \\
\hline School's Quality Assurance & $\begin{array}{l}\text { ETQ Reliance, Compliance Quest, Qualizone, MeasureUp Audit Applications, } \\
\text { Netwrix Auditor. }\end{array}$ \\
\hline $\begin{array}{l}\text { Policies compliance \& } \\
\text { management }\end{array}$ & PowerDMS, Policy Manager, MyCompliance, SurveilStar. \\
\hline $\begin{array}{l}\text { Learning Management Sys- } \\
\text { tems (LMS) }\end{array}$ & $\begin{array}{l}\text { Moodle, Canvas, Blackboard Learn, Schoology, Edmodo, Google Classroom, } \\
\text { Open EdX, TalentLMS, Easy LMS, Docebo. }\end{array}$ \\
\hline Poll \& survey & $\begin{array}{l}\text { Mentimeter, Poll Everywhere, Google Forms, SurveyMonkey. LimeSurvey, } \\
\text { Zoho Survey, Pollmaker, iClicker. }\end{array}$ \\
\hline Test \& quiz & Quizlet, Quizizz, Kahoot!, Socrative, ProProfs, Seesaw. \\
\hline Assessments & Socrative, Google Forms, GoFormative, ProProfs, Padlet, TopHat, Kahoot! \\
\hline Search engines & $\begin{array}{l}\text { Google, Baidu, Yahoo, Bing, Yandex, DuckDuckGo, Infotopia, Google } \\
\text { Scholar, Microsoft Academic. }\end{array}$ \\
\hline $\begin{array}{l}\text { Digital repositories \& data- } \\
\text { bases }\end{array}$ & $\begin{array}{l}\text { Merlot, OER Commons, DOER, OpenStax, Europeana, Library of Congress, } \\
\text { Wikipedia, ClassCentral, Khan Academy, YouTube, iTunesU, Bitbucket, } \\
\text { GitHub. }\end{array}$ \\
\hline MOOC providers & $\begin{array}{l}\text { Coursera, edX, FutureLearn, OpenLearn, Udacity, Udemy, SWAYAM, } \\
\text { XuetangX, Miriadax, FUN, ThaiMOOC, Federica, NPTEL, CNMOOC. }\end{array}$ \\
\hline Office & Microsoft Office, Google Docs, Apple iWork. \\
\hline Presentations & $\begin{array}{l}\text { MS PowerPoint, Google Slides, Apple Keynote, Prezi, Sway, Zoho, Pear } \\
\text { Deck, NearPod, Class Dojo, Projeqt. }\end{array}$ \\
\hline Photo editing & $\begin{array}{l}\text { Adobe Lightroom, GIMP, Adobe Photoshop, Google Photos, Corel PaintShop, } \\
\text { Capture One, ACDSee Photo Studio, GIMP. }\end{array}$ \\
\hline Audio editing & $\begin{array}{l}\text { Soundcloud, Vocaroo, Audacity, Online Voice Recorder, Audio Memos, Easy } \\
\text { Voice Recorder, VoiceThread, Kaizena. }\end{array}$ \\
\hline Video editing & $\begin{array}{l}\text { Adobe Premiere, Apple iMovie, Corel VideoStudio Ultimate, CyberLink Pow- } \\
\text { erDirector, Animoto, Kaltura, Camtasia, Filmora, CyberLink PowerDirector, } \\
\text { Filmora, DaVinci Resolve, VideoPad, HitFilm Express, YouTube Video editor. }\end{array}$ \\
\hline Microblogging & Twitter, Tumblr, SinaWeibo, Plurk, Yammer, Qaiku. \\
\hline Blogging & $\begin{array}{l}\text { WordPress, Blogger, Open Diary, TypePad, Vox, Expression, Engine, Xanga, } \\
\text { Edublogs, Tumblr, Medium, Ghost. }\end{array}$ \\
\hline Wiki & $\begin{array}{l}\text { Wikipedia, Wikiversity, Wikimedia, Wikispaces, Wiki site, Baidu Baike, } \\
\text { Evernote, Twiki, PBWorks, Doku Wiki, Tiki Wiki, Media WiKi. }\end{array}$ \\
\hline Websites & WordPress, Adobe D, Weebly, Wix, Jimdo, Strikingly. \\
\hline Course authoring & $\begin{array}{l}\text { Articulate, Easygenerator, iSpring, Adobe Captivate, Lectora, isEazy, gomo } \\
\text { Learning, Evolve, Elucidat. }\end{array}$ \\
\hline Simulations & Matlab, Wolfram Mathematica. \\
\hline Games & Classcraft, Kahoot!, Minecraft, Unity Learn, Socrative. \\
\hline Calendar & $\begin{array}{l}\text { Apple Calendar, Google Calendar, Microsoft Outlook Calendar, Microsoft } \\
\text { Exchange Server, Yahoo Calendar, Cal Calendar, Jorte Calendar, Business } \\
\text { Calendar, Calendar, aCalendar, DigiCal Calendar, SolCalendar, Any.do, } \\
\text { Cozi, My Study Life. }\end{array}$ \\
\hline
\end{tabular}




\begin{tabular}{|c|c|}
\hline Scheduling & Doodle, Calendar, Calendly. \\
\hline Lesson Planning & PlanbookEdu, OnCourse Lesson Planner, LessonWriter. \\
\hline Project management & $\begin{array}{l}\text { Asana, Trello, EdModo, Open Project, OpenProj, Project Libre, MSproject, } \\
\text { Basecamp, Launchpad, Gantt chart, PERT. }\end{array}$ \\
\hline Class management & Dyknow, ClassDojo, LanSchool, Classe365. \\
\hline Plagiarism checker & $\begin{array}{l}\text { Turnitin, iThenticate, Ginger, Grammarly, DupliChecker, Copyleaks, Paper- } \\
\text { Rater, WhiteSmoke Plagiarism Checker, ProWritingAid. }\end{array}$ \\
\hline Antivirus & $\begin{array}{l}\text { Bitdefender Antivirus, Norton AntiVirus, Kaspersky Antivirus, Webroot Se- } \\
\text { cureAnywhere Antivirus, Avast Antivirus, ESET Antivirus. }\end{array}$ \\
\hline Security suites & $\begin{array}{l}\text { McAfee (Total Protection, LiveSafe), Symantec Norton 360, Bitdefender (In- } \\
\text { ternet Security, Total Security), Kaspersky (Internet Security, Security Cloud), } \\
\text { Webroot SecureAnywhere Internet Security, Trend Micro (Internet Security, } \\
\text { Maximum Security), Avast Internet Security. }\end{array}$ \\
\hline Conferencing and Webinars & $\begin{array}{l}\text { Zoom, Google Meet, Skype, FaceTime, Adobe Connect, BigBlueButton, Cisco } \\
\text { Webex Meetings, Jitsi, BlueJeans, GoToMeeting, Join.me. }\end{array}$ \\
\hline Podcasting & $\begin{array}{l}\text { Podcast, GarageBand, Audacity, Reaper, Logic Pro, Adobe Audition, Skype, } \\
\text { Zoom. }\end{array}$ \\
\hline Video platforms & $\begin{array}{l}\text { Vimeo, YouTube, Instagram, Bilibili, Twitch, Dailymotion, Niconico, Qzone, } \\
\text { VK, Vine. }\end{array}$ \\
\hline File Hosting \& Sharing & Google Drive, Google Docs, Dropbox, SlideShare, ownCloud, OneDrive. \\
\hline Photo Hosting \& Sharing & Instagram, Flickr, Pinterest, Qzone, VK. \\
\hline Audio Hosting \& Sharing & iTunes, SoundCloud, Spotify, Libre.fm, Pandora, Qzone, VK, Last.fm. \\
\hline Video Hosting \& Sharing & $\begin{array}{l}\text { Vimeo, YouTube, Instagram, Bilibili, Twitch, Dailymotion, Niconico, Qzone, } \\
\text { VK, Vine. }\end{array}$ \\
\hline Email & Gmail, Zoho Email, MS Outlook, Apple Mail. \\
\hline Messaging & Facebook messenger, WhatsApp, Snapchat, Viber, Kakao Talk, Line. \\
\hline Mind mapping & $\begin{array}{l}\text { FreeMind, XMind, Mindmeister, Mindomo, Bubbl.us, Mubu, Coggle, Popplet, } \\
\text { Mind42 online, Cmap, Mimdjet. }\end{array}$ \\
\hline Student response systems & $\begin{array}{l}\text { iClicker, TopHat, Socrative, Acadly, PollEverywhere, Text2MindMap, } \\
\text { ClassDojo. }\end{array}$ \\
\hline Team collaboration & Google Docs, Padlet, Edmodo, Microsoft Teams, Slack, SharePoint. \\
\hline Virtual whiteboards & Stoodle, Stormboard, Explain Everything. \\
\hline Social media & Facebook, Instagram, Linkedin. \\
\hline Collaborative games & Classcraft, Socrative. \\
\hline Portfolios & $\begin{array}{l}\text { We.seesaw, Silk, Google Sites, Weebly, LiveBinder, Digication, Pebble Pad, } \\
\text { Taskstream, Wix, Weebly, WordPress, Kindblog, Three Ring, Evernote, } \\
\text { Google Sites, Wikispaces for Education, Seesaw, Pathbrite. }\end{array}$ \\
\hline Web quests & $\begin{array}{l}\text { Zunal WebQuest Maker, Quest Garden, Aula 21, Teachnology Web Quest } \\
\text { Maker. }\end{array}$ \\
\hline Quiz games & Kahoot!,Socrative, Quizziz, Quizlet live, Badaboom. \\
\hline Monitoring people & $\begin{array}{l}\text { LMS, Class Dojo, NetSupport School, TeacherEase, Edmodo, Classroom Spy } \\
\text { Pro, Teramind, ActivTrak, Flexispy, SoftActivity, SAM, Beestar Insight, } \\
\text { LOCO-Analyst, LAN Employee Monitor ActivTrak, SniperSpy. }\end{array}$ \\
\hline $\begin{array}{l}\text { Monitoring resources \& in- } \\
\text { frastructure }\end{array}$ & $\begin{array}{l}\text { Datadog, Paessler PRTG, Spiceworks, SolarWinds, NetSpot, LabStats, } \\
\text { SpyAgent, ActivTrack, Logic Monitor, Dynatrace, dbWatch, SQL Power } \\
\text { Tools, Redgate SQL Monitor, Site } 24 X 7, \text { Nagios, Opsview, Net Flow Analyzer, } \\
\text { ManageEngine, Zabbix, OpenNMS, Retrace, Icinga, WhatsUp Gold, Auvik, } \\
\text { NinjaRMM. }\end{array}$ \\
\hline Website monitoring & $\begin{array}{l}\text { Freshping, LogicMonitor, Uptimerobot, Uptime.com, GTmetrix, Montastic, } \\
\text { Pingdom, Monitis, AppDynamics, New Relic Browser, SmartBear AlertSite, } \\
\text { Google Analytics. }\end{array}$ \\
\hline Social media monitoring & Hootsuite, TweetReach, if This Then That (IFTTT), HowSociable, SumAll. \\
\hline Learning analytics & YET Analytics, BrightBytes, Knewton, Clever, Panopto. \\
\hline
\end{tabular}




\begin{tabular}{|l|l|}
\hline Dashboards & Grafana, Tableau, Freeboard, Dashbuilder, Redash. \\
\hline Avatars and chatbots & $\begin{array}{l}\text { IBM's Watson, Google's DeepMind, Apple's Siri, Google Assistant, Google } \\
\text { Now, Microsoft's Cortana, MobileMonkey, Pandorabots, Blackboard's } \\
\text { Snatchbot. }\end{array}$ \\
\hline Feedback & $\begin{array}{l}\text { QuestionPro, Kaizena, Spiral, Classkick, Formative, Brightloop, Echograde, } \\
\text { Voxer, Remind, Crowd Signal, Kahoot, Socrative, Mentimeter, piHappiness. }\end{array}$ \\
\hline Diaries & Penzu, Journalate, Diaro, Diary, Journey, Momento. \\
\hline Note-taking & Evernote, OneNote, Google Keep, Post it Plus, OneNote, Padlet. \\
\hline Online proctoring & Respondus, ProctorU, Proctorio, Mettl, Examity, PSI Services. \\
\hline
\end{tabular}

